\title{
Study of Carbonaceous and Nitrogenous Pollutant Removal Efficiencies in a Hybrid Membrane Bioreactor
}

\author{
Victor S. Ruys, Kamel Zerari, Isabelle Seyssiecq, and Nicolas Roche \\ Aix-Marseille University, CNRS, Centrale Marseille, M2P2 UMR 7340, 13541 Marseille Cedex 13, France \\ Correspondence should be addressed to Nicolas Roche; nicolas.roche@univ-amu.fr
}

Received 8 March 2017; Revised 25 April 2017; Accepted 11 May 2017; Published 8 June 2017

Academic Editor: Carlos Alberto Lberto Martínez-Huitle

Copyright (C) 2017 Victor S. Ruys et al. This is an open access article distributed under the Creative Commons Attribution License, which permits unrestricted use, distribution, and reproduction in any medium, provided the original work is properly cited.

\begin{abstract}
A hybrid membrane bioreactor (HMBR) comprises activated sludge (free biomass), a biofilm (supported biomass), and a membrane separation. A laboratory pilot-scale HMBR was operated for seven months with high organic loads of both carbonic and nitrogen pollutants. Several experiments were conducted to investigate the influence of the height of the packing bed $(27 \mathrm{~cm}, 50 \mathrm{~cm}$, and $0 \mathrm{~cm})$ and the effect of the concentration of dissolved oxygen (DO) on the organic removal rate, total nitrogen removal rate (TN), and ammonium removal. The organic removal rate was always $>95 \%$ and mostly $>98 \%$. The $\mathrm{NH}_{4}{ }^{+}-\mathrm{N}$ and TN removal rates were directly related to DO. $\mathrm{NH}_{4}{ }^{+}$-N removal rate reached $100 \%$ and was mostly $>99 \%$ with a concentration of DO $>0.1 \mathrm{mg} / \mathrm{L}$, whereas the $\mathrm{NO}_{3}{ }^{-}-$ $\mathrm{N}$ removal rate was differentially affected depending on the level of DO. The removal rate increased when the concentration of DO was optimal for simultaneous nitrification and denitrification, which was between 0.1 and $0.5 \mathrm{mg} / \mathrm{l}$, and the TN removal rate was consequently high. The removal rate decreased when DO was high and denitrification was consequently low thereby reducing the TN removal rate. This implies that high levels of DO $(>1 \mathrm{mg} / \mathrm{L})$ limit the denitrification process and low levels of DO $(<0.1 \mathrm{mg} / \mathrm{L})$ limit the nitrification process and hence total nitrogen removal in the bioreactor.
\end{abstract}

\section{Introduction}

Today, an increasing number of surface water resources suffer from eutrophication. The increased nutriment loads in the sewage and the discharge of inadequately treated wastewater and industrial water into water resources are the main causes of this phenomenon.

It is therefore important to find more efficient processes to remove the increased pollution and to protect water resources. Processing using a hybrid membrane bioreactor (HMBR) first depends on the combined effect of a suspended activated sludge (free bacteria) and a biofilm (supported bacteria) which make it possible to enhance removal efficiency compared to a conventional activated sludge (AS) process [1]. The use of membrane technology for the separation of free bacteria from the liquid phase also improves the efficiency of treatment. Carriers are used to minimize the negative effect of suspended solids, reduce the formation of a membrane cake layer thanks to the scouring effects of suspended carriers, minimize fouling, and improve nutrient removal and filterability [2-8]. In a previous work [8] the benefits of gas-liquid mass transfer and of adding a packing bed in the bioreactors for different solutions (water, suspension, and nonNewtonian fluid) were demonstrated.

HMBR combines classical organic carbon depollution with simultaneous nitrification and denitrification. Biological nitrification-denitrification is a development process for nitrogen removal from wastewater. On the one hand and during the nitrification step, ammonia-oxidizing bacteria (AOB) aerobically oxidize the ammonium to nitrite after which the nitrite is oxidized to nitrate by nitrite-oxidizing bacteria (NOB). On the other hand, during the denitrification step, nitrate is reduced to gaseous nitrogen by denitrifying microorganisms [9]. Shortcut biological nitrogen removal (SBNR) [10] is based on partial nitrification to nitrite followed by nitrite denitrification (Figure 1).

However, the stability of nitrite accumulation, which is a key prerequisite for successful SBNR, is a major challenge to the implementation of this process. One major problem is that nitrifiers with low growth rate can be washed out in the conventional activated sludge process, resulting in a reduction in the nitrification performance. To overcome this 


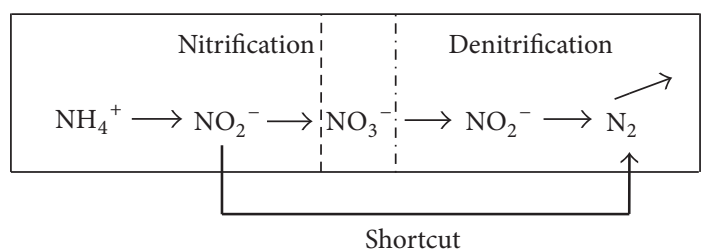

FIGURE 1: Biological nitrogen removal by nitrification-denitrification.

problem, a submerged membrane bioreactor (MBR) is introduced to improve nitrification efficiency because membrane filtration enables complete separation of solids and liquids and maintains a high level of autotrophic biomass in the reactor [11].

Degradation is influenced by the filling fraction of carriers, the extent of biofilm growth, the concentration of MLSS in suspended growth, and biomass activity. The 1/3 lower concentration of biomass in the attached form can reach the same removal rates as biomass in the suspended form [12].

The aBF-MBR has higher specific oxygen uptake rates (SOUR) compared to conventional AS-MBR [13, 14]. But, with similar hydraulic retention times (HRTs) and sludge retention times (SRTs), both systems can achieve 95-99\% of chemical oxygen demand (COD) removals and there is no significant difference in the nitrification rate, which is $>96 \%$. However, some authors found that AS-MBR has 2-4\% lower nitrification rate compared to aBF-MBR $[6,14]$.

aBF-MBR enables higher total nitrogen removal because of simultaneous nitrification/denitrification (SND) in deeper biofilm layers $[2,12,14]$.

According to Gupta and Sharma [15], biological oxidation of high strength nitrogenous wastewater (TKN $=1.0$ to $1.1 \mathrm{~kg} / \mathrm{m}^{3}$ ) was successful after the feed was supplemented with an external source of organic carbon to raise the COD : TKN ratio to nearly 1 . Over $96 \%$ nitrification and up to $99 \%$ TKN removal were achieved with a SRT of $30 \mathrm{~d}$ and a HRT of $2 \mathrm{~d}$.

Mines and Sherrard [16] observed incomplete nitrification (40 to $65 \%$ with SRTs of, resp., 17 and $21 \mathrm{~d}$ ) with an influent of $0.5 \mathrm{~kg} \mathrm{TKN} \cdot \mathrm{m}^{-3}$. In a reciprocating jet bioreactor, 85 to $95 \%$ of the influent ammonium $\left(0.65-0.85 \mathrm{~kg} \mathrm{NH}_{4}{ }^{+}-\right.$ $\mathrm{N} \cdot \mathrm{m}^{-3}$ ) was converted at a low HRT (4.2 h) [17]. In this case, an antifoaming agent should be introduced to avoid excessive formation of foam.

According to Charmot-Charbonnel et al. [18], aerated submerged fixed beds have a high nitrification capacity which enables distribution of the wastewater over the whole biofilm. In the case of the treatment of fertilizer waste containing $0.5 \mathrm{~kg} \mathrm{NH}{ }_{4}^{+}-\mathrm{N} \cdot \mathrm{m}^{-3}$ in an upflow biofilm reactor, removal rates can reach up to $0.6 \mathrm{~kg} \mathrm{NH}{ }_{4}^{+}-\mathrm{N} \cdot \mathrm{m}^{-3} \cdot \mathrm{d}^{-1}$ (or $13.2 \mathrm{~kg}$ $\mathrm{NH}_{4}{ }^{+}-\mathrm{N} \cdot \mathrm{m}^{-2} \cdot \mathrm{d}^{-1}$ ) and 90.6 to $99 \%$ of ammonium removal was achieved with an ammonium volumetric loading of 0.4 to $0.6 \mathrm{~kg} \cdot \mathrm{m}^{-3} \cdot \mathrm{d}^{-1}$. Nitrification stopped when the concentration of ammonium-N reached $5 \mathrm{~kg} \cdot \mathrm{m}^{-3}$ (or $B_{v}=2.6 \mathrm{~kg} \mathrm{NH}_{4}{ }^{+}$$\left.\mathrm{N} \cdot \mathrm{m}^{-3} \cdot \mathrm{d}^{-1}\right)$, as indicated by the low ammonium removal rate (7\%).
Simultaneous nitrification-denitrification has already been observed in other biofilm reactors, for example, rotating biological contactors (RBC) [19].

Tang et al. [20] used a multihabitat membrane bioreactor to investigate the DO distribution and the factors influencing the mass transfer of DO. Different proportions of COD:TN:TP of synthetic water and low aeration rate were used to obtain an aerobic or an anoxic status. The accumulation of biomass was the main factor which influenced the distribution of DO to the different zones. Organic and ncontaining substances could be removed simultaneously, but the effective removal of TN was only possible after obvious anoxic and aerobic zones were formed within the bioreactor.

The objective of the present study was to evaluate the impact of the concentration of dissolved oxygen (DO) on simultaneous nitrification and denitrification (SND) in a HMBR for the treatment of high load wastewater. The effect of enriched attached culture seeded on the packing in HMBR was also studied to understand their role in SND.

\section{Material and Methods}

Experiments were carried out in a bioreactor (a cylindrical clear PVC column) with and without a packing bed. The column used was $15.3 \mathrm{~cm}$ in diameter (ID), $126.5 \mathrm{~cm}$ in total height (HT), filled with $91 \mathrm{~cm}$ of liquid (HL), and packed with either $27 \mathrm{~cm}$ or $54 \mathrm{~cm}$ (HS) of filling material (Figure 2).

Cylindrical solid packing rings (AnoxKaldnes ${ }^{\circledR}$ rings) made of polyethylene (about $10 \mathrm{~mm}$ in diameter and $7 \mathrm{~mm}$ in height) were used in the experiments. Their main geometrical characteristics are summarized in Table 1.

In order to prevent the loss of packing material due to recirculating liquid, the packing rings were held in place by two grids with $0.5 \mathrm{~mm}$ apertures located just above and under the bed. Compressed air was supplied by a compressor and was injected at the bottom of the column using a porous disc diffuser.

Air flow rates were measured using a flowmeter (SHORATE). The liquid phase was recirculated from the bottom to the top of the bioreactor by a centrifuge pump and the flow rate was measured using a ROSE-MOUNT 4 X flowmeter. The concentration of dissolved oxygen in the bioreactor was measured using an oxygen electrode oximeter HQ30D (Hach Lange), equipped with a temperature sensor. Gas input ranged between $60 \mathrm{~L} / \mathrm{h}$ and $180 \mathrm{~L} / \mathrm{h}$. The flow rate of the recirculated liquid was set between 200 and $300 \mathrm{~L} / \mathrm{h}$ to prevent sludge accumulating in the membrane channels and to ensure complete mixing. It was previously shown that an increase in the recirculated flow rate had no significant effects on the measured $K_{L} a$ [8]. A ceramic microfiltration membrane Carbosep ${ }^{\circledR}$ (pore size: $0.1 \mu \mathrm{m}$, area: $0.0226 \mathrm{~m}^{2}$ ) with six channels was used in the system to separate the activated sludge from the purified water during normal operation (i.e., in presence of activated sludge in the bioreactor and continuous feeding with substrate).

The substrate, which was prepared every two or three days in a $50 \mathrm{~L}$ tank, consisted of sugar, meat extract (Viandox $\left.^{\circledR}\right)$, ammonium chloride $\left(\mathrm{NH}_{4} \mathrm{Cl}\right)$, sodium bicarbonate $\left(\mathrm{NaHCO}_{3}\right)$, and phosphoric acid $\left(\mathrm{H}_{3} \mathrm{PO}_{4}\right)$. For a $\mathrm{COD}$ equal 


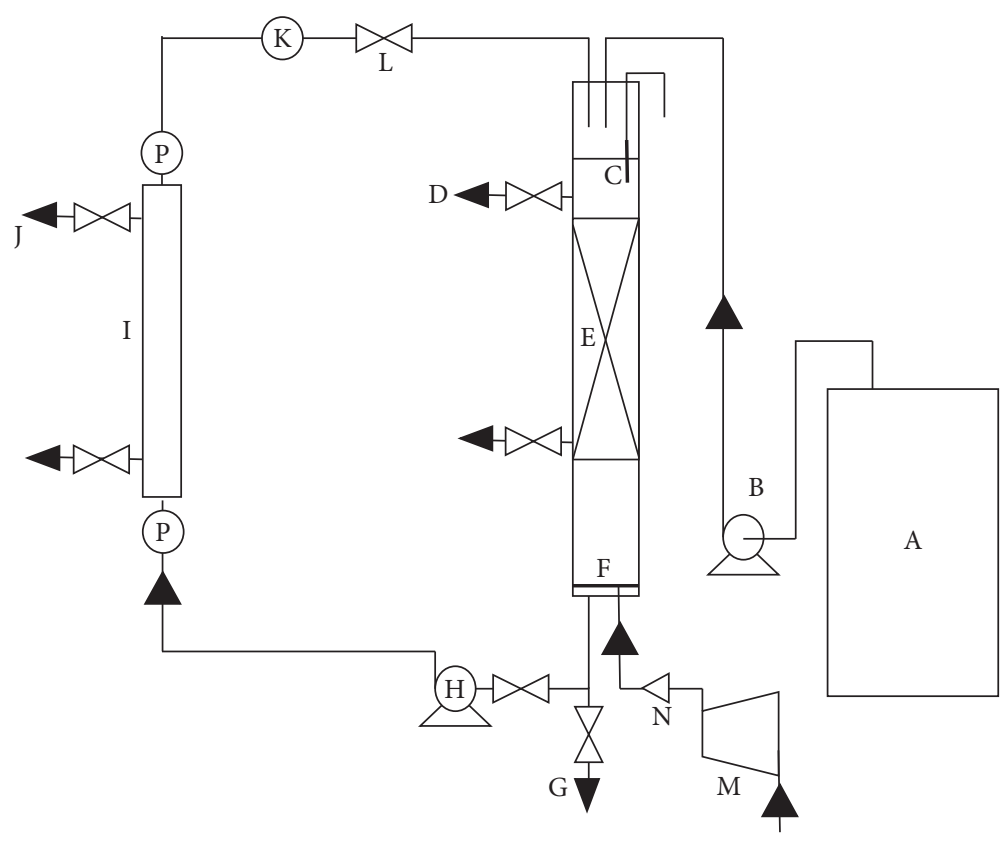

Figure 2: Experimental setup of laboratory pilot scale; A: feeding tank; B: dosing pump; C: oximeter; D: sampling; E: fixed bed; F: porous diffuser; G: discharge valve; H: recirculation pump; I: membrane; J: outlet valve; K: liquid flowmeter; L: valve water; M: compressor; N: gas flowmeter.

TABLE 1: Physical packing characteristics (AnoxKaldnes rings).

\begin{tabular}{lcccc}
\hline Parameter & $\begin{array}{c}\text { Density } \\
\rho_{s}\left(\mathrm{~kg} / \mathrm{m}^{3}\right)\end{array}$ & Porosity $\varepsilon(-)$ & $\begin{array}{c}\text { Diameter } \\
d_{p}(\mathrm{~mm})\end{array}$ & $\begin{array}{c}\text { Specific area } \\
a\left(\mathrm{~m}^{2} / \mathrm{m}^{3}\right)\end{array}$ \\
\hline Value & 968 & 0,79 & 10 & 1000 \\
\hline
\end{tabular}

to $1,000 \mathrm{mg} / \mathrm{L}$, the following proportions were used: $39 \mathrm{~g}$, $42.5 \mathrm{~g}, 11.5 \mathrm{~g}, 33.33 \mathrm{~g}$, and $0.75 \mathrm{~mL}$ of sugar, meat extract, $\mathrm{NH}_{4} \mathrm{Cl}, \mathrm{NaHCO}_{3}$, and $\mathrm{H}_{3} \mathrm{PO}_{4}$, respectively. A constant and continuous feeding inlet flowrate of about $1 \mathrm{~L} / \mathrm{h}$ was applied. The same proportions but with bigger quantities were used for higher pollutant loads.

The ammonium $\mathrm{N}-\mathrm{NH}_{4}{ }^{+}$and the nitrates $\mathrm{N}-\mathrm{NO}_{3}{ }^{-}$were measured by an ammonium meter SC200 (Hach Lange). pH was measured by a pH-meter HANNA (pH210). Mixed liquor suspended solids (MLSS) for suspended bacteria: $30 \mathrm{~mL}$ of mixed liquor was centrifuged for 15 minutes at $13500 \mathrm{rpm}$ with a SIGMA 2-16 centrifuge; the solid part was then dried at $105^{\circ} \mathrm{C}$ for 24 hours. The MLSS was the percentage difference in weight before and after drying. The mass of the fixed bacteria on the packing material was calculated monthly by measuring the difference in weight in some pieces of packing before and after drying. The chemical oxygen demand (COD) of the substrate, of the supernatant, and of the permeate was measured using one of the two following methods: first, using CHE Metrics COD tubes and an Aquamate ThermoSpectronic spectrophotometer; second, using measured total organic carbon (TOC) to deduce the COD using an experimental calibration curve between COD values and TOC. Total organic carbon (TOC) and total nitrogen were measured by TOC-VCPH (Total Organic Carbon Analyzer) SHIMADZU.
At the beginning of the pilot operation, activated sludge from the recirculation line of the Aix-en-Provence (France) WWTP was seeded into the bioreactor to provide a concentration of mixed liquor suspended solids (MLSS) of $2.7 \mathrm{~g} / \mathrm{L}$ which increased after several days to reach about $3.5 \mathrm{~g} / \mathrm{L}$ MLSS concentration.

A mean MLSS concentration of 3.0-4.5 g/L was maintained by removing a precise volume of sludge from the bioreactor every day. MLVSS was calculated several times over the whole operation period. The MLVSS/MLSS ratio was always around 0.92 .

The membrane was cleaned when the permeate flow rate dropped to about $0.5 \mathrm{~L} / \mathrm{h}$.

Operating Conditions. The pilot operation was run for 166 consecutive days divided into three phases according to the packing height, phase I (0-79 d) with a bed height of $27 \mathrm{~cm}$, phase II (80-153 d) with a bed height of $54 \mathrm{~cm}$, and phase III (153-170) with no packing bed. Each phase comprised several periods of one or two weeks corresponding to specific operating conditions in terms of the concentration of inlet pollutant and the air flowrate (i.e., one operating parameter was changed from one period to the other). The different operating conditions are detailed in Table 2 . The applied loading rates (from 2.9 to $8.2 \mathrm{kgCOD} /(\mathrm{m} 3 \cdot \mathrm{d}$ ) for carbonaceous pollution and from 0.19 to $0.55 \mathrm{kgN} /(\mathrm{m} 3 \cdot \mathrm{d})$ for nitrogenous pollution) can be considered as high. 
TABLE 2: Operational conditions of the HMBR.

\begin{tabular}{|c|c|c|c|c|c|c|c|c|}
\hline $\begin{array}{l}\text { Height of } \\
\text { packing bed } \\
(\mathrm{cm})\end{array}$ & $\begin{array}{c}\text { Number of } \\
\text { period }\end{array}$ & $\begin{array}{l}\text { Number of } \\
\text { days in the } \\
\text { period }\end{array}$ & $\begin{array}{l}\text { Accumulated } \\
\text { time from } \\
\text { day to day }\end{array}$ & $\begin{array}{c}\text { Concentration } \\
\text { of COD at the } \\
\text { inlet } \\
\mathrm{Kg} / \mathrm{m}^{3}\end{array}$ & $\begin{array}{c}\text { Concentration } \\
\text { of } N_{\text {total }} \\
\mathrm{Kg} \mathrm{N} / \mathrm{m}^{3}\end{array}$ & $\begin{array}{c}\text { Air } \\
\text { flowrate } \\
\text { L/h }\end{array}$ & $\begin{array}{l}\text { Average COD } \\
\text { loading rate } \\
\mathrm{kgCOD} /\left(\mathrm{m}^{3} \cdot \mathrm{d}\right)\end{array}$ & $\begin{array}{l}\text { Average } N_{\text {total }} \\
\text { loading rate } \\
\operatorname{kgN} /\left(\mathrm{m}^{3} \cdot \mathrm{d}\right)\end{array}$ \\
\hline \multirow{9}{*}{$\begin{array}{l}\text { Phase I } \\
27 \mathrm{~cm}\end{array}$} & 1 & 16 & $1-16$ & $250-1000$ & $16-65$ & 120 & & \\
\hline & 2 & 10 & $17-26$ & \multirow{2}{*}{2000} & \multirow{2}{*}{135} & 120 & \multirow{2}{*}{2,87} & \multirow{2}{*}{0,19} \\
\hline & 3 & 7 & $27-33$ & & & 60 & & \\
\hline & 4 & 8 & $34-41$ & \multirow{2}{*}{2500} & \multirow{2}{*}{165} & & \multirow{2}{*}{3,59} & \multirow{2}{*}{0,24} \\
\hline & 5 & 8 & $42-49$ & & & 120 & & \\
\hline & 6 & 10 & $50-59$ & \multirow{2}{*}{3000} & \multirow{2}{*}{202} & 120 & \multirow{2}{*}{4,30} & \multirow{2}{*}{0,29} \\
\hline & 7 & 7 & $60-66$ & & & 60 & & \\
\hline & 8 & 7 & $67-73$ & \multirow{2}{*}{5000} & \multirow{2}{*}{335} & & \multirow{2}{*}{7,17} & \multirow{2}{*}{0,48} \\
\hline & 9 & 6 & $74-79$ & & & 120 & & \\
\hline \multirow{9}{*}{$\begin{array}{l}\text { Phase II } \\
54 \mathrm{~cm}\end{array}$} & 10 & 10 & $80-89$ & \multirow{2}{*}{3000} & \multirow{2}{*}{202} & 180 & \multirow{2}{*}{4,30} & \multirow{2}{*}{0,29} \\
\hline & 11 & 14 & 90-103 & & & 60 & & \\
\hline & 12 & 7 & $104-110$ & \multirow{3}{*}{5700} & \multirow{3}{*}{380} & & \multirow{3}{*}{8,18} & \multirow{3}{*}{0,55} \\
\hline & 13 & 8 & 111-118 & & & 120 & & \\
\hline & 14 & 11 & $119-129$ & & & 180 & & \\
\hline & 15 & 5 & $130-134$ & \multirow{4}{*}{4000} & \multirow{4}{*}{270} & 100 & & \\
\hline & 16 & 5 & $135-139$ & & & 60 & \multirow{3}{*}{5,74} & \multirow{3}{*}{0,39} \\
\hline & 17 & 9 & $140-148$ & & & 120 & & \\
\hline & 18 & 5 & $149-153$ & & & 60 & & \\
\hline \multirow{2}{*}{$\begin{array}{l}\text { Phase III } \\
0 \mathrm{~cm}\end{array}$} & 19 & 6 & $154-159$ & \multirow{2}{*}{4000} & \multirow{2}{*}{270} & & \multirow{2}{*}{5,74} & 0,39 \\
\hline & 20 & 7 & $160-166$ & & & 120 & & \\
\hline
\end{tabular}

The applied loading rates, the removal efficiencies, and the removal rates have been, respectively, calculated by the classical formulas with for

(i) the applied loading rate $\left(L_{v}\right.$ in $\left.\mathrm{kg} / \mathrm{m}^{3} \cdot \mathrm{d}\right): L_{v}=\left(\left([S]_{\text {in }}\right.\right.$. Q) $/ V) \cdot 24$,

(ii) the removal efficiencies $(E$ in $\%): E=\left(1-[S]_{\text {out }} /[S]_{\text {in }}\right)$. 100 ,

(iii) the removal rate $\left(R_{v}\right.$ in $\left.\mathrm{kg} / \mathrm{m}^{3} \cdot \mathrm{d}\right): R_{v}=\left(L_{V} \cdot E\right) / 100$,

where $[S]_{\text {in }}$ is the concentration $\left(\mathrm{kg} / \mathrm{m}^{3}\right)$ of COD, or $\mathrm{TN}$, or $\mathrm{NH}_{4}{ }^{+}-\mathrm{N}$ in the influent, $[S]_{\text {out }}$ is the concentration $\left(\mathrm{kg} / \mathrm{m}^{3}\right)$ of $\mathrm{COD}$, or $\mathrm{TN}$, or $\mathrm{NH}_{4}{ }^{+}-\mathrm{N}$ at the outlet, $\mathrm{Q}$ is the influent flowrate $\left(\mathrm{m}^{3} / \mathrm{h}\right)$, and $V$ is the volume of the bioreactor $\left(\mathrm{m}^{3}\right)$.

\section{Results and Discussion}

The results of the whole experiment are summarized for each period (mean values) in Table 3 including DO concentration, COD removal rates, and nitrogen removal rates and in Figure 3 as a function of time.

On the one hand, the difference in treatment efficiency between phase I and phase II revealed a notable effect of bed height. Phase III allowed us to compare the difference between CMBR and HMBR in terms of pollutant removal efficiency. On the other hand, the concentration of the feed and the dissolved oxygen concentration appeared to be the key to simultaneous nitrification and denitrification efficiency.

The first period is not discussed because it corresponds to acclimation of the activated sludge to the synthetic substrate. Acclimation was considered to be complete when the COD removal efficiency and activated growth yield were constant, in this case, after 16 days.

Because an easily biodegradable synthetic substrate was used, whatever the operating conditions, the COD removal efficiency was very high in all the periods. Increasing the height of the packing bed made it possible to enhance the aerobic conditions in the bioreactor because of the increase of oxygen mass transfer in the bioreactor as it has been shown in the previous work of Zerari et al. [8] and hence to increase the volumetric efficiency of the bioreactor, for the aerobic biodegradation of the pollutants, with a COD removal rate of about $8 \mathrm{kgCOD} / \mathrm{m}^{3} \cdot \mathrm{d}$ for periods 12,13 , and 14 compared to the higher level of COD removal rate obtained in phase I (periods 8 and 9) of about $7 \mathrm{kgCOD} / \mathrm{m}^{3} \cdot \mathrm{d}$.

For the nitrogen compounds, removal efficiencies were linked to the aerobic or anoxic conditions in the bioreactor. In periods 8 and 9 , nitrification efficiency was reduced to about $68 \%$. In this configuration, there was clearly a limit to nitrification with a maximum TN removal rate of about $0.33 \mathrm{kgN} /$ $\mathrm{m}^{3} \cdot \mathrm{d}$. It was possible to enhance the removal rate, that is, the volumetric efficiency of the bioreactor, by increasing of the height of the packing bed. In periods 13,14 , and 18, with 
TABLE 3: Experimental removal rates and removal efficiencies.

\begin{tabular}{|c|c|c|c|c|c|c|c|c|}
\hline $\begin{array}{l}\text { Packing } \\
\text { height Cm }\end{array}$ & $\begin{array}{l}\text { Number of } \\
\text { period }\end{array}$ & $\begin{array}{c}\text { Air flow rate } \\
\mathrm{L} / \mathrm{h}\end{array}$ & $\begin{array}{c}\text { Average DO } \\
\mathrm{mg} / \mathrm{L}\end{array}$ & $\begin{array}{c}\mathrm{COD} \\
\text { removal rate } \\
\mathrm{kg} \\
\mathrm{COD} / \mathrm{m}^{3} \cdot \mathrm{d}\end{array}$ & $\begin{array}{l}\text { TN removal } \\
\text { rate } \\
\mathrm{kg} \mathrm{N} / \mathrm{m}^{3} \cdot \mathrm{d}\end{array}$ & $\begin{array}{c}\text { COD } \\
\text { removal } \\
\text { efficiency\% }\end{array}$ & $\begin{array}{c}\mathrm{NH}_{4}^{+}-\mathrm{N} \\
\text { removal } \\
\text { efficiency\% }\end{array}$ & $\begin{array}{c}N_{\text {total }} \text { removal } \\
\text { efficiency } \%\end{array}$ \\
\hline \multirow{9}{*}{$\begin{array}{l}\text { Phase I } \\
27 \mathrm{Cm}\end{array}$} & 1 & 120 & 5.5 & - & - & 61,1 & 62.2 & 2.2 \\
\hline & 2 & 120 & 4.3 & 2,71 & 0,015 & 94,6 & 95.1 & 7.7 \\
\hline & 3 & 60 & 0.5 & 2,68 & 0,18 & 93,5 & 97.7 & 92.8 \\
\hline & 4 & 60 & 0.59 & 3,46 & 0,228 & 96,6 & 99.1 & 96.3 \\
\hline & 5 & 120 & 1.62 & 3,51 & 0,13 & 97,9 & 99.6 & 55.02 \\
\hline & 6 & 120 & 1.66 & 4,22 & 0,18 & 98 & 99.76 & 62.1 \\
\hline & 7 & 60 & 0.36 & 4,24 & 0,28 & 98,6 & 98.4 & 96.6 \\
\hline & 8 & 60 & 0.28 & 7,04 & 0,315 & 98,2 & 66.8 & 65.5 \\
\hline & 9 & 120 & 1.7 & 7,05 & 0,322 & 98,3 & 68.5 & 67 \\
\hline \multirow{9}{*}{$\begin{array}{l}\text { Phase II } \\
54 \mathrm{Cm}\end{array}$} & 10 & 180 & 4.17 & 4,23 & 0,235 & 98,2 & 84.2 & 81.1 \\
\hline & 11 & 60 & 0.86 & 4,2 & 0,279 & 97,5 & 99.5 & 96.3 \\
\hline & 12 & 60 & 0.11 & 8,04 & 0,41 & 98,3 & 76.4 & 75.2 \\
\hline & 13 & 120 & 0.18 & 8,06 & 0,401 & 98,6 & 75.4 & 73.6 \\
\hline & 14 & 180 & 1.23 & 8,08 & 0,374 & 98,8 & 71.4 & 68.6 \\
\hline & 15 & 180 & 2.14 & 5,66 & 0,218 & 98,7 & 59.2 & 56.4 \\
\hline & 16 & 60 & $0.66-0.1$ & 5,64 & 0,192 & 98,3 & 56 & 49.6 \\
\hline & 17 & 120 & 0.16 & 5,65 & 0,304 & 98,5 & 82.9 & 78.6 \\
\hline & 18 & 60 & 0.39 & 5,65 & 0,365 & 98,4 & 96.8 & 94.2 \\
\hline \multirow{2}{*}{$\begin{array}{l}\text { Phase III } \\
0 \mathrm{Cm}\end{array}$} & 19 & 60 & 0.73 & 5,63 & 0 & 98,2 & 97 & $\begin{array}{c}\text { Continuous } \\
\text { decrease }\end{array}$ \\
\hline & 20 & 120 & 4.08 & 5,6 & 0 & 97,6 & 99.6 & $\begin{array}{l}\text { Continuous } \\
\text { decrease }\end{array}$ \\
\hline
\end{tabular}

a packing bed height of $54 \mathrm{~cm}$, nitrogen removal rates were $0.4 \mathrm{kgN} / \mathrm{m}^{3} \cdot \mathrm{d}$. With this HMBR, it was impossible to obtain higher nitrogen removal rates. The packing bed in the bioreactor had two combined effects; it enabled an increase in the concentration of the biomass in the bioreactor with the presence of a biofilm and also in the rate of oxygen mass transfer in the bioreactor.

Nitrification efficiency, that is, $\mathrm{NH}_{4}{ }^{+}-\mathrm{N}$ removal efficiency, depended to a great extent on the aerobic conditions in the bioreactor. The highest efficiency rate, $>95 \%$, was obtained in periods $3,4,5,6,7,18,19$, and 20 with a DO concertation $>0.4 \mathrm{mg} / \mathrm{l}$ of dissolved oxygen in the bioreactor. When the DO level was too low, nitrification in the bioreactor was limited due to lack of oxygen, as observed in periods 8 , 12 , and 16.

Denitrification was only achieved in anoxic conditions. With a DO level $<1.0 \mathrm{mg} / \mathrm{L}$, the biofilm could be considered to be in anoxic conditions and denitrification occurred (periods 3, 4, 7, 8, 11, 12, 13, 16, 17, and 18).

It was also possible to remove all the nitrogen at the same time (simultaneous nitrification and denitrification) with aerobic conditions in the activated sludge and anoxic conditions in the biofilm obtained by controlling the level of DO in the bioreactor. DO levels of between 0.5 and $1 \mathrm{mg} / \mathrm{L}$ were observed in periods 4,11 , and 18 , with simultaneous and complete nitrification and denitrification in the HMBR with nitrogen removal efficiency observed of about $95 \%$ for those periods. These periods have to be compared, respectively, to the periods 5,10 , and 17 with the same loading rates and higher air flow rates and DO levels. The assumption of simultaneous nitrification and denitrification could be made because of a constant amount of carbonaceous consumption observed (same COD removal efficiencies) and because it was not necessary to add carbonaceous compounds to achieve complete nitrification-denitrification in those periods, possibly due to a shortcut in the biological nitrogen removal process $\left(\mathrm{NO}_{2}^{-}\right.$to $\mathrm{N}_{2}$, as it has been described in the literature: Figure 1).

In periods 7 and 11 , the height of the packing bed was seen to affect the efficiency of the oxygenation transfer. In the same operating conditions, that is, with the same loading rates and air flow rate, a higher concentration of DO was observed with a $54 \mathrm{~cm}$ packing bed $(0.86 \mathrm{mg} / \mathrm{L}$ in period 11) than with a $27 \mathrm{~cm}$ packing bed $(0.36 \mathrm{mg} / \mathrm{L}$ in period 7). It confirms the fact that the height of the packing bed has a positive effect on the oxic conditions in the bioreactor.

In phase III, the bioreactor was operated with no packing bed, that is, like a classical AS process. A continuous decrease in nitrification efficiency was observed because with no biofilm in the reactor, it is impossible to obtain anoxic conditions 


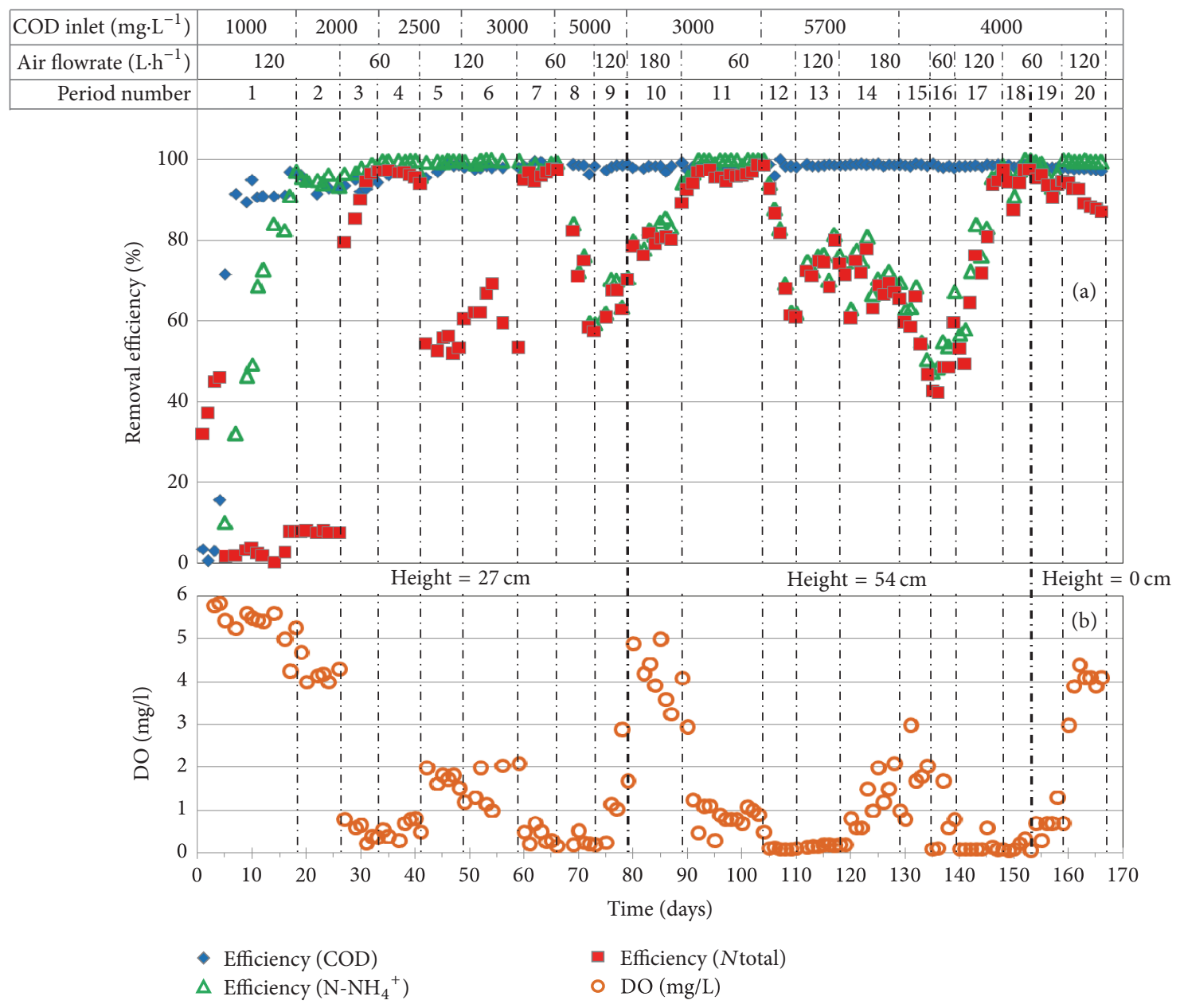

Figure 3: Removal efficiencies for a COD; ${\mathrm{N}-\mathrm{NH}_{4}}^{+} ; \mathrm{N}$ total; and (b) DO concentrations as a function of time.

and simultaneous nitrification and denitrification, due to continuous aeration.

\section{Conclusions}

An innovative HMBR configuration enabled improved depollution efficiency without increasing the amount of suspended bacteria in the mixed liquor. Compared to classical membrane bioreactors (MBR), HMBR thus makes it possible to treat highly loaded wastewaters while reducing problem of fouling caused the use of low concentration of MLSS.

HMBR also enabled highly efficient nitrification and denitrification thanks to the development of a biofilm on the inert surface of the filling material and the presence of both aerobic and anoxic conditions in the reactor. This configuration efficiently removes nitrates and nitrites by controlling the concentrations of dissolved oxygen in the reactor. The most important factors controlling the correct functioning of the reactor are thus the concentration of dissolved oxygen and the height of the packing bed. Simultaneous nitrification and denitrification enabled high removal efficiencies with concentrations of dissolved oxygen between 0.4 and $0.9 \mathrm{~mL} / \mathrm{L}$.
The HMBR configuration made it possible to increase the efficiency of oxygen transfer with no additional energy consumption and with an increase in the volumetric efficiency of pollutant removal in the bioreactor.

\section{Disclosure}

An earlier version of this work was presented as an abstract at 10th European Congress of Chemical Engineering, France, 2014.

\section{Conflicts of Interest}

The authors declare that there are no conflicts of interest regarding the publication of this paper.

\section{References}

[1] M. Kraume and A. Drews, "Membrane bioreactors in waste water treatment-status and trends," Chemical Engineering of Technology, vol. 33, no. 8, pp. 1251-1259, 2010.

[2] J. Lee, W.-Y. Ahn, and C.-H. Lee, "Comparison of the filtration characteristics between attached and suspended growth 
microorganisms in submerged membrane bioreactor," Water Research, vol. 35, no. 10, pp. 2435-2445, 2001.

[3] W.-N. Lee, I.-J. Kang, and C.-H. Lee, "Factors affecting filtration characteristics in membrane-coupled moving bed biofilm reactor," Water Research, vol. 40, no. 9, pp. 1827-1835, 2006.

[4] X. C. Wang, Q. Liu, and Y. J. Liu, "Membrane fouling control of hybrid membrane bioreactor: Effect of extracellular polymeric substances," Separation Science and Technology, vol. 45, no. 7, pp. 928-934, 2010.

[5] K. Sombatsompop, C. Visvanathan, and R. Ben Aim, "Evaluation of biofouling phenomenon in suspended and attached growth membrane bioreactor systems," Desalination, vol. 201, no. 1-3, pp. 138-149, 2006.

[6] Z. Liang, A. Das, D. Beerman, and Z. Hu, "Biomass characteristics of two types of submerged membrane bioreactors for nitrogen removal from wastewater," Water Research, vol. 44, no. 11, pp. 3313-3320, 2010.

[7] X. Huang, C.-H. Wei, and K.-C. Yu, "Mechanism of membrane fouling control by suspended carriers in a submerged membrane bioreactor," Journal of Membrane Science, vol. 309, no. 1-2, pp. 7-16, 2008.

[8] K. Zerari, I. Seyssieq, D.-E. Akretche, and N. Roche, "Enhancement of oxygen mass transfer coefficients in a hybrid membrane bioreactor," Journal of Chemical Technology and Biotechnology, vol. 88, no. 6, pp. 1007-1013, 2013.

[9] G. Dotro, B. Jefferson, M. Jones, P. Vale, E. Cartmell, and T. Stephenson, "A review of the impact and potential of intermittent aeration on continuous flow nitrifying activated sludge," Environmental Technology, vol. 32, no. 15, pp. 1685-1697, 2011.

[10] L. Qiu and J. Ma, "A novel approach to remove nitrogen in a biological aerobic filter (BAF)," Environmental Technology, vol. 26, no. 8, pp. 923-930, 2005.

[11] S.-H. Yoon and S. Lee, "Critical operational parameters for zero sludge production in biological wastewater treatment processes combined with sludge disintegration," Water Research, vol. 39, no. 15, pp. 3738-3754, 2005.

[12] Q. Liu, X. C. Wang, Y. Liu, H. Yuan, and Y. Du, "Performance of a hybrid membrane bioreactor in municipal wastewater treatment," Desalination, vol. 258, no. 1-3, pp. 143-147, 2010.

[13] S. Jamal Khan, S. Ilyas, S. Javid, C. Visvanathan, and V. Jegatheesan, "Performance of suspended and attached growth MBR systems in treating high strength synthetic wastewater," Bioresource Technology, vol. 102, no. 9, pp. 5331-5336, 2011.

[14] S. Yang, F. Yang, Z. Fu, and R. Lei, "Comparison between a moving bed membrane bioreactor and a conventional membrane bioreactor on organic carbon and nitrogen removal," Bioresource Technology, vol. 100, no. 8, pp. 2369-2374, 2009.

[15] S. K. Gupta and R. Sharma, "Biological oxidation of high strength nitrogenous wastewater," Water Research, vol. 30, no. 3, pp. 593-600, 1996.

[16] R. O. Mines and J. H. Sherrard, "Biological treatment of a high strength nitrogenous wastewater," Journal of Environmental Science and Health, vol. 32, no. 5, pp. 1353-1375, 1997.

[17] K. H. Radwan and T. K. Ramanujam, "Influence of COD/ $\mathrm{NH}_{3}$ $\mathrm{N}$ ratio on organic removal and nitrification using a modified RBC," Bioprocess Engineering, vol. 16, no. 2, pp. 77-81, 1997.

[18] M.-L. Charmot-Charbonnel, S. Herment, N. Roche, and C. Prost, "Nitrification of high strength ammonium wastewater in an aerated submerged fixed bed," Environmental Progress, vol. 18, no. 2, pp. 123-129, 1999.
[19] S. K. Gupta, S. M. Raja, and A. B. Gupta, "Simultaneous nitrificationdenitrification in a rotating biological contactor," Environmental Technology, vol. 15, no. 2, pp. 145-153, 1994.

[20] B. Tang, B. Qiu, S. Huang et al., "Distribution and mass transfer of dissolved oxygen in a multi-habitat membrane bioreactor," Bioresource Technology, vol. 182, pp. 323-328, 2015. 

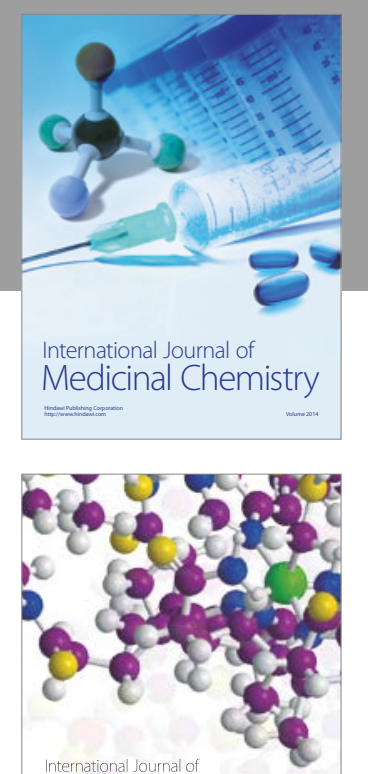

Carbohydrate Chemistry

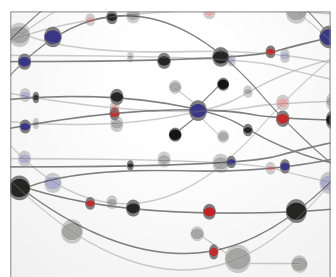

The Scientific World Journal
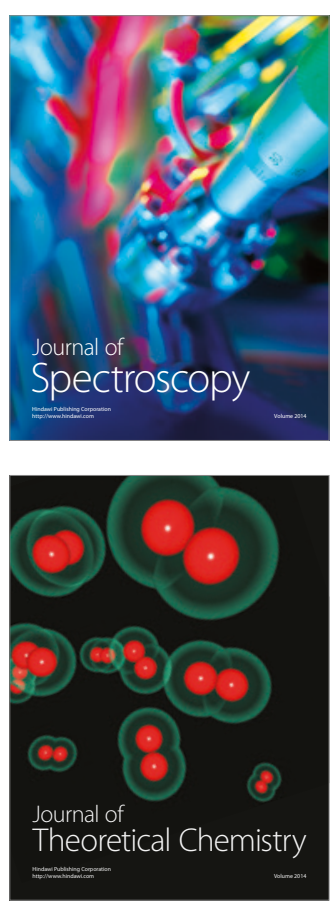
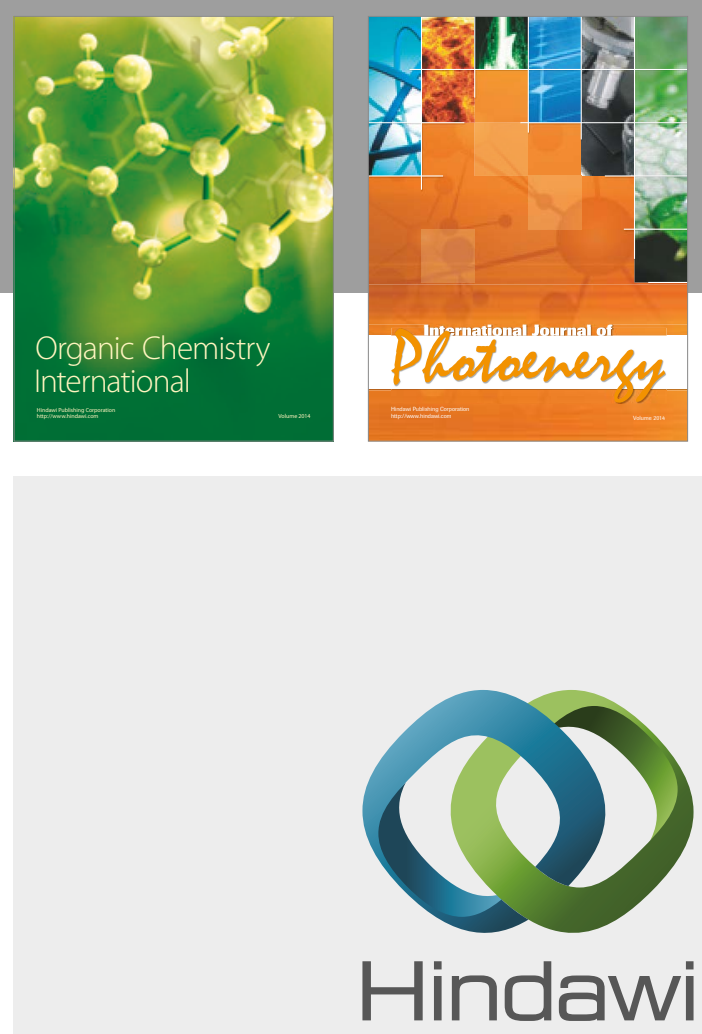

Submit your manuscripts at

https://www.hindawi.com

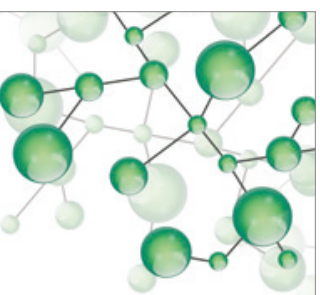

International Journal of

Inorganic Chemistry

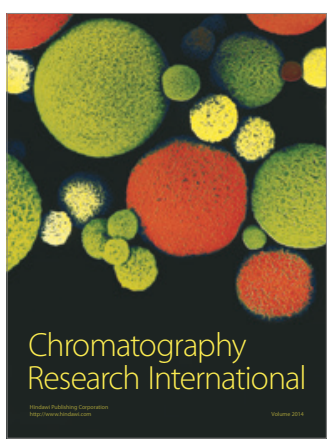

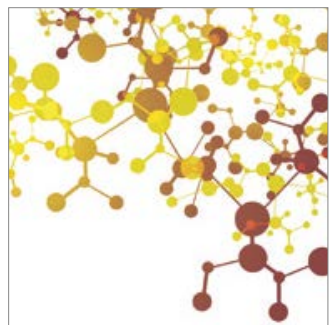

Applied Chemistry
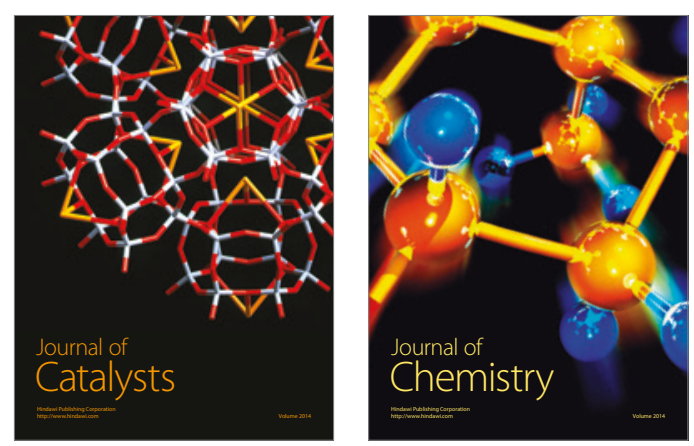
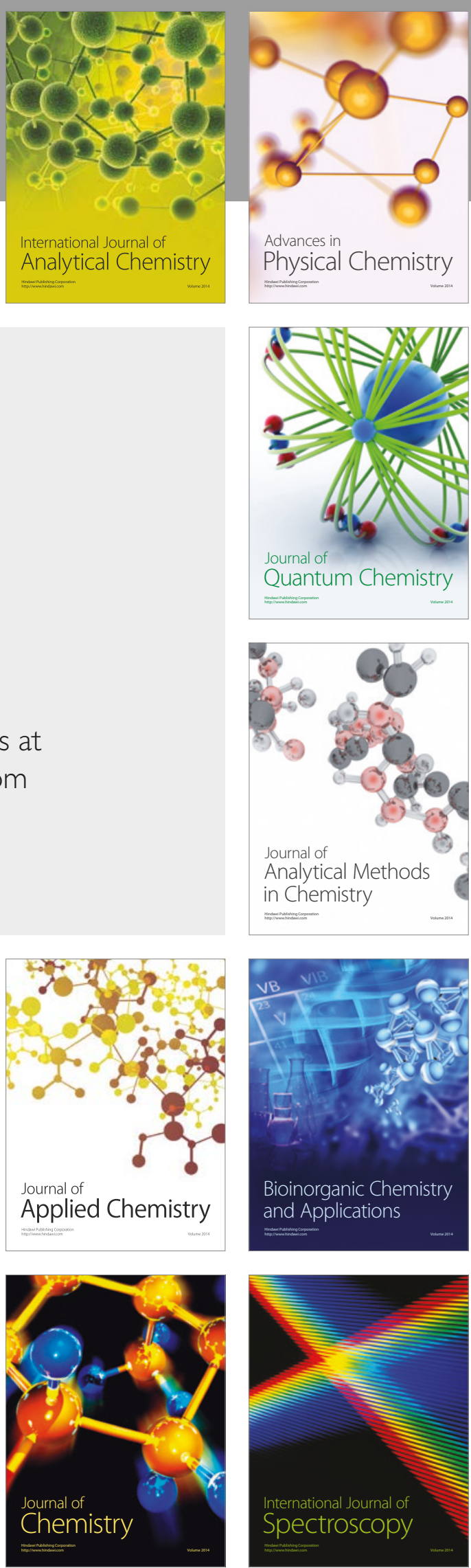